\title{
Optymalne obciążenia poznawcze pracownika
}

\author{
Grażyna Wieczorkowska*, Magdalena Sieradzka**
}

Celem artykutu jest próba syntezy wiedzy dotyczacej przeciążenia/niedociażenia poznawczego pracowników, które ma wymierne konsekwencje dla efektów ich pracy. Tok wywodu zorganizowano $w$ postaci 4 tez. (1) Efektywność wykonywania zadań zależy krzywoliniowo od PAO (poziomu aktywacji organizmu) pracownika (Yerkes i Dodson, 1908). Zależność ta jest efektem wptywu PAO na wielkość aktualnie dostępnych zasobów poznawczych. Wpływ emocji na poziom pobudzenia organizmu zależy od ich typu. (2) Wielkość pobudzenia tonicznego wyznaczaja przede wszystkim cechy temperamentalne. Moderatorem zwiazku PAO z temperamentem moga być zarówno stałe cechy osobowościowe czy sytuacja socjodemograficzna, jak i cechy zmienne, takie jak poziom zmęczenia (niewyspanie, przeziębienie...). (3) Pobudzenie fazowe pracownika zależy nie tylko od obiektywnej sytuacji bodźcowej i wykonywanej aktywności, ale jest także moderowane przez automatycznie działajace filtry percepcyjne, schematy poznawcze i celowa aktywność poznawcza przypisujaca znaczenie bodźcom. (4) Pracownik zazwyczaj aktywnie wptywa na PAO podejmując działania o określonej wartości stymulacyjnej. Widoczne sa duże różnice w preferencjach co do typu stymulacji (intelektualna, fizyczna, spoteczna...).

Słowa kluczowe: przeciążenie, ekstrawersja, typ stymulacji, poziom aktywacji organizmu, wielozadaniowość.

Nadesłany: 06.10.18 | Zaakceptowany do druku: 17.12.18

\section{The optimum cognitive load of the employee}

The goal of the current article is an attempt to synthesize the knowledge on the consequences of cognitive overload/underload of the employees on their work outcomes. The course of the argument has been organized in the form of 4 theses. (1) Employee performance depends curvilinearly on the level of arousal (Yerkes $i$ Dodson, 1908). This relationship is affected by the size of the available cognitive resources. The effect of emotions on the level of arousal depends on their type. (2) The magnitude of tonic arousal is primarily defined by the temperamental traits. The relationship between the arousal level and the temperament can be moderated by permanent personality traits, sociodemographic situation, as well as variable features, such as the level of fatigue (lack of sleep, cold...). (3). Employee's phasic arousal depends not only on the objective stimuli and performed activity, but can also be moderated by the automatically operating perceptual filters, cognitive schemas, and a deliberate cognitive activity aimed at assigning meaning to the stimuli. (4). An employee can actively influence his/her arousal level by undertaking activities of a certain stimulative value. There are large differences regarding the type of preferred stimulation (intellectual, physical, social...).

\footnotetext{
* Grażyna Wieczorkowska - prof. zw. dr hab., Uniwersytet Warszawski, Wydział Zarządzania.

** Magdalena Sieradzka - mgr, Uniwersytet Warszawski, Wydział Zarządzania.

Adres do korespondencji: Wydział Zarządzania, Uniwersytet Warszawski, ul. Szturmowa 1/3, 02-678 Warszawa; e-mail: wierzbinska@wz.uw.edu.pl, sieradzka.magdalena@gmail.com.
} 
Keywords: overload, extroversion, type of stimulation, level of arousal, multitasking.

Submitted: 06.10.18 | Accepted: 17.12.18

JEL: J24

\section{Wprowadzenie}

Żyjemy w czasach natłoku informacji, kiedy dramatycznie ulega skróceniu czas koncentracji na jednym bodźcu, spłyca się poziom przetwarzania (np. skanowanie tekstu, a nie jego czytanie), wzrasta przeciążenie poznawcze. Nasze mózgi nie są przystosowane do takiego informacyjnego natłoku i zdarza się, że w wyniku przeciążenia odmawiają dalszego zapamiętywania. Coraz częściej u osób cieszących się dobrym zdrowiem i bez żadnych zaburzeń neurologicznych nagle występują trwające kilka godzin głębokie zaburzenia pamięci, polegające na niemożności zapamiętania jakichkolwiek informacji dłużej niż przez kilkadziesiąt sekund (Ziomek i Brola, 2006). W takim stanie nie odnotowuje się żadnych zaburzeń świadomości (orientacja co do własnej osoby oraz rozpoznawanie innych osób są zachowane); wyższe funkcje korowe obejmujące mowę, liczenie, gnozję i praksję oraz myślenie abstrakcyjne są prawidłowe. U wielu osób zachowana jest także zdolność wykonywania złożonych czynności, np. prowadzenia samochodu. Wygląda to tak, jakby „twardy dysk” odmawiał przyjmowania kolejnych informacji. Po parogodzinnym odpoczynku stan mija, nie pozostawiając żadnych konsekwencji poza luką pamięciową z czasu trwania zaburzenia.

$\mathrm{Z}$ przeciążeniem mamy coraz częściej do czynienia w miejscu pracy i temu zagadnieniu przyjrzymy się w tym artykule. Aby nie przeciążać Czytelnika, używamy paru skrótów:

YD = prawa Yerkesa-Dodsona

PAO - poziom aktywacji organizmu pracownika

WM - Working Memory - Pamięć Operacyjna

WR vs NR - określa krańce na wymiarze reaktywności - Wysoko reaktywni vs. Nisko reaktywni pracownicy

SSA - Sondaż Stylów Aktywności

\section{Poziom aktywacji organizmu [PAO] i pojemność pamięci operacyjnej}

Punktem wyjścia dla modelu pomiaru obciążenia poznawczego pracownika są prawa Yerkesa-Dodsona (1908) mówiące, że:

1) optymalne funkcjonowanie w pracy osiagane jest przy optymalnym $\mathrm{z}$ indywidualnego punktu widzenia poziomie aktywacji organizmu,

2) optymalny poziom pobudzenia zależy od trudności zadania - im zadanie trudniejsze, tym mniejszy poziom pobudzenia jest optymalny.

Rysunek 1. Schematyczny wykres zależności między PAO a poziomem wykonania dla zadań prostych i trudnych

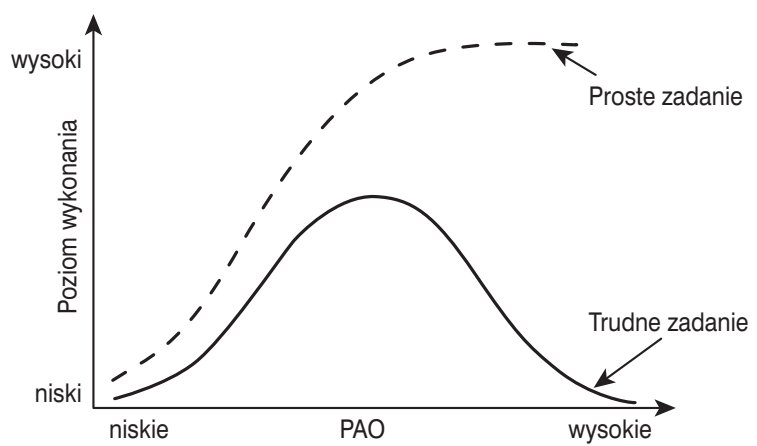

Źródło: opracowanie własne na podstawie literatury.

$\mathrm{Na}$ rysunku 1 przedstawiony jest schematyczny wykres zależności między PAO a poziomem wykonania zadań w zależności od ich trudności. Związek efektywności wykonania zadań (jakkolwiek byśmy jej nie operacjonalizowali) $\mathrm{z}$ poziomem pobudzenia organizmu (operacjonalizowanym często przez poziom stresu, motywacji...) ma kształt odwróconego „U”: do pewnego stopnia wzrost pobudzenia poprawia wykonanie zadania, a następnie wraz $\mathrm{z}$ dalszym jego przyrostem poziom wykonania zadania zaczyna spadać. W przypadku zadań trud- 
nych zbyt duże PAO dość szybko pogarsza wykonanie. W przypadku prostych zadań wzrost PAO prowadzi do poprawy poziomu wykonania, aż do osiagnnięcia plateau, kiedy to dalszy wzrost nie jest już możliwy.

Przez OPTYMALNY poziom wykonania zadania rozumiemy zarówno bezbłędne, jak i szybkie wykonanie zadania w sposób nieprowadzący do przeciążenia (pojęcie wyjaśnione w dalszej części tekstu). Wszyscy subiektywnie jesteśmy w stanie określić takie sytuacje, w których praca „pali nam się w rękach”, wykonujemy zadania bardzo efektywnie, często jesteśmy w stanie FLOW. Optymalny poziom wykonania zadań np. kierowcy autobusu to jazda bezwypadkowa i terminowa bez wchodzenia w niepotrzebne konflikty z pasażerami i innymi kierowcami. Na tym przykładzie widać, że pojęcie optymalnego poziomu wykonania jest wielowymiarowe i wysokokontekstowe - musi być operacjonalizowane dla każdej pracy/zadania osobno. Prawo Yerkesa-Dodsona opisuje wykonanie zadań wymagających wykorzystania posiadanych przez pracownika umiejętności. Optymalny poziom pobudzenia może też zostać określony w procesie uczenia się wykonywania danej aktywności. Proces uczenia się również wymaga zwiększonego poziomu pobudzenia organizmu. Wykazano, że mózg lubi być zaskakiwany - uwalniane są wtedy adrenalina i kortyzol, które powodują lepsze zapamiętywanie zdarzeń emocjonujących niż neutralnych. Bez zwiększonego pobudzenia zapis pamięciowy jest więc dużo słabszy.

Oczywiste jest, że poziom wykonania zadań zależy od wielkości zasobów poznawczych, czyli aktualnej pojemności pamięci operacyjnej. Terminem PAMIĘĆ OPERACYJNA (WM: Working Memory) określa się proces przetwarzania informacji świeżo nabytych i/lub wydobytych z pamięci długotrwałej.

Najważniejszą cechą WM jest jej ograniczona pojemność. W pamięci długotrwałej może być wiele zaktywizowanych (gotowych od użycia) elementów (information chunks), ale WM nie jest w stanie pomieścić ich wszystkich równocześnie. Ratuje nas mechanizm skupiania uwagi, który pozwala na przełączanie pomiędzy zaktywizowanymi elementami. Ograniczenia co do liczby elementów, na których mogą być wykonywane operacje jednocześnie są przełamywane dzięki ciągłemu składaniu infor- macji w większe porcje (ang. chunking) lub tworzeniu ciągów skojarzeń (Duch, 2018). Pojemność WM można „powiększyć”, notujac informacje na kartce.

Pojemność WM można analizować jako cechę pracownika lub aktualny stan. Badania wykonywane za pomoca standardowych testów wykazują duże różnice indywidualne w pojemności WM, które korelują z poziomem inteligencji (IQ). Aktualna pojemność WM zależeć też może od ilości informacji w niej „rezydujących”. Ograniczenie pojemności aktualnie dostępnej pamięci operacyjnej powoduje upośledzenie efektywności wykonywania zadań.

Trzeba pamiętać, że zasoby poznawcze (pamięć operacyjna) stanowią pewną całość, obejmując możliwości nie tylko poznawcze, lecz także emocjonalne, wolicjonalne itp. Wiemy, że możliwości przetwarzania informacji spadają pod wpływem choroby, niewyspania... Trafniejszą nazwą powinny być więc zasoby psychoenergetyczne.

Na wielkość zasobów poznawczych, czyli aktualną pojemność pamięci operacyjnej, wpływa zarówno poziom pobudzenia (zbyt niski powoduje, że kiepsko się nam rozwiązuje problemy, zbyt wysoki powoduje uproszczone przetwarzanie informacji), jak i rezydujące $\mathrm{w}$ pamięci informacje, niedokończone zadania. Przykładem wpływu PAO na przetwarzanie informacji mogą być wyniki badań pokazujące, że „sowy” myślą stereotypowo rano, zaś „skowronki” wieczorem (Bodenhausen, 1990). Analogicznie wpływają na przetwarzanie informacji silne emocje.

Stopień „obciążenia poznawczego” jest definiowany przez aktualną pojemność pamięci operacyjnej (wielkość zasobów poznawczych) w relacji do wartości stymulacyjnej pracy i otoczenia, $w$ jakim ta praca jest wykonywana. Porównanie wartości stymulacyjnej bodźców oddziałujących na pracownika (bodźce zewnętrzne oraz sygnały wewnętrzne przekładające się poziom aktywacji organizmu pracownika) z wielkością AKTUALNIE dostępnych zasobów poznawczych wyznaczanych przez aktualną pojemność pamięci operacyjnej pozwala określić stopień obciążenia pracownika. To porównanie może zaowocować stwierdzeniem:
1) optymalnego poziomu obciążenia poznawczego,
2) przeciążenia lub
3) niedociążenia. 
Pojęcie przeciążenia odnosi się do sytuacji, w których system poznawczy nie jest w stanie kompensować dostępnymi zasobami wymagań stawianych przed nim przez aktualnie wykonywane zadania. Warto brać pod uwagę także dodatkowe czynniki związane $\mathrm{z}$ kontekstem i środowiskiem wykonania zadania, np. ustawienie przerw w pracy, komfort i warunki wykonania zadania (hałas, oświetlenie, temperatura itp.). Zarówno typ, jak i czas zadania determinują natężenie obciążenia poznawczego: np. proste, ale za długie zadanie może być bardzo obciążające, podobnie jak zadanie krótkie, ale za to intensywne.

Kiedyś uważano, że pobudzenie „energetyzuje, ale nie kieruje". Neuroobrazowanie mózgu pokazuje, że tylko emocje pozytywne aktywizują ośrodki nagrody, negatywne - choć równie pobudzające - nie. Różne emocje kierują uwagę na różne treści, co wpływa na kodowanie i zapamiętywanie.

Wysoki PAO może być zarówno przyjemny, jak np. w ferworze pracy, jak i przykry - np. gdy dowiadujemy się o porażce. W pierwszym przypadku odczuwamy pobudzenie energetyczne, $w$ drugim pobudzenie napięciowe (Thayer, 1989). Analogicznie, niski poziom pobudzenia może być przyjemny - np. kąpiel po ciężkim dniu pracy (niskie pobudzenie napięciowe) lub nieprzyjemny, np. odczuwana senność, brak energii na początku dnia pracy (niskie pobudzenie energetyczne). Oba typy pobudzenia mogą współwystępować - wiadomość o niespodziewanej wizycie ważnej dla nas osoby może nas mobilizować do sprzątania (pobudzenie energetyczne) i jednocześnie paraliżować, bo zagraża naszej samoocenie (pobudzenie napięciowe). Ważne jest przy tym także uwzględnianie dynamiki czasowej - aktywacja wyjaśniania zadziałaniem bodźca może nie tylko wygasać, ale także zmieniać swój charakter z nieprzyjemnej na przyjemną (np. efekt ćwiczeń fizycznych) lub odwrotnie (np. efekt zjedzenia słodyczy).

Przeżywane emocje wpływają na PAO, przy czym warto pamiętać o rozróżnieniu na:

- emocje podnoszace poziom pobudzenia (steniczne, takie jak złość) vs obniżające (asteniczne, takie jak smutek)

- emocje automatyczne, reaktywne: homeostatyczne vs hedonistyczne) vs refleksyjne, oparte na namyśle i pojęciach wartościujących (Jarymowicz i Imbir, 2010).

Zarówno w badaniach, jak i w codziennym życiu łatwo można wpływać na ilość zasobów poznawczych za pomocą dodatkowego zadania - np. prosząc uczestników o zapamiętanie na czas pobytu w laboratorium ośmiocyfrowej liczby, wykonywanie równolegle innych poleceń, powstrzymywanie ekspresji mimicznej podczas oglądania emocjonalnego materiału filmowego. W wielu badaniach pokazano, że ograniczenia wielkości aktualnie dostępnych zasobów poznawczych nie zakłóca przebiegu procesów automatycznych, procesy kontrolowane są jednak w takiej sytuacji zatrzymywane.

\section{Wielkość pobudzenia tonicznego wyznaczają przede wszystkim cechy temperamentalne}

$\mathrm{Na}$ PAO pracownika składają się pobudzenie toniczne (pomiar w stanie relaksacji) i pobudzenie fazowe (pomiar w sytuacji reakcji na bodziec).Ważnym elementem ograniczającym skuteczność funkcjonowania pracownika są możliwości energetyczne wyznaczone przez temperament, które wyznaczają poziom pobudzenia tonicznego i wpływają na poziom pobudzenia fazowego przede wszystkim bodźców o ekstremalnym natężeniu (Strelau, 2006).

Najczęściej badane w tym kontekście cechy temperamentu to reaktywność, ekstrawersja poszukiwanie doznań (Strelau, 2006). Reaktywność definiujemy jako stosunek siły reakcji do siły bodźca. Niektórzy wykładowcy, gdy mówią o tym na wykładzie, w tym momencie przewracają krzesło (co jest zaskoczeniem). Część osób podskakuje w reakcji na ten niespodziewany bodziec, część zaś siedzi spokojnie. Ten sam bodziec, a jak różna siła reakcji. Osoby silnie reagujące na bodźce określamy mianem wysoko reaktywnych (WR). Osoby nisko reaktywne (NR) reagują słabiej niż wysoko reaktywne na bodźce o tej samej sile.

Sprawa reaktywności nie jest tak banalnie prosta, jakby się mogło zdawać, bowiem należy pamiętać, że nie reagujemy na bezpośredni bodziec, a na jego znaczenie (o czym piszemy więcej w punkcie 3 ).

Możemy określać reaktywność (siłę reakcji w stosunku do siły bodźca) dla każdego analizatora i otrzymać różne wyniki 
dla wzroku, słuchu, węchu. Najczęściej badana jest reaktywność emocjonalna, więc parcjalność reaktywności różnych analizatorów jest $\mathrm{w}$ diagnozie reaktywności pomijana. W SSA ${ }^{1}$ reaktywność jest operacjonalizowana za pomocą wskaźnika zbudowanego z odpowiedzi na pytania zawarte $\mathrm{w}$ ramce 1 .

Ramka 1.

\begin{tabular}{|c|l|}
\hline s1 & $\begin{array}{l}\text { Osoba A zawsze gorzej sypia PRZED ważnym wydarzeniem (egzaminem, daleką } \\
\text { podróżą). Osoba B należy do osób odpornych na stres. }\end{array}$ \\
\hline s2 & $\begin{array}{l}\text { Osoba A bardzo dobrze funkcjonuje „za pięć dwunasta”. Presja czasowa dezorganizuje } \\
\text { zachowanie osoby B. }\end{array}$ \\
\hline s3 & $\begin{array}{l}\text { Ood ciśnieniem stresu osoba A paradoksalnie czuje się lepiej niż wtedy, gdy wszystko idzie } \\
\text { ustalonym trybem. Osoba B nie lubi być „pod ciśnieniem”. }\end{array}$ \\
\hline s4 & $\begin{array}{l}\text { Po ukończeniu stresującej pracy osoba A łatwo się relaksuje. Osoba B potrzebuje dużo } \\
\text { czasu, aby „odtajać”. }\end{array}$ \\
\hline s5 & $\begin{array}{l}\text { Kiedy jest zbyt wiele rzeczy do zrobienia, osoba A zaczyna panikować. Osoba B spokojnie } \\
\text { realizuje punkt po punkcie. }\end{array}$ \\
\hline s6 & $\begin{array}{l}\text { Gdy zadania zaczynają przekraczać jej możliwości, osoba A zachowuje spokój, osoba B } \\
\text { jest „kłębkiem nerwów”. }\end{array}$ \\
\hline s8 & $\begin{array}{l}\text { Osoba A pod presją podejmuje decyzje łatwiej niż wtedy, gdy ma dużo czasu. } \\
\text { Osoba B nie lubi podejmować decyzji w warunkach presji czasowej. }\end{array}$ \\
\hline s9 & Osobę A męczy chaos, nadmiar informacji. Osobę B bardziej męczy monotonia. \\
\hline
\end{tabular}

$\mathrm{Na}$ ekstrawersję składają się: towarzyskość, żywość, aktywność, asertywność, poszukiwanie doznań. Ekstrawertycy są przyjacielscy i serdeczni, towarzyscy i rozmowni, skłonni do zabawy oraz poszukiwania stymulacji. Wykazują tendencję do dominowania w kontaktach społecznych i są życiowo aktywni oraz pełni wigoru. Wykazuja optymizm życiowy i pogodny nastrój. Introwertycy są ich przeciwieństwem. W SSA ekstrawersja jest operacjonalizowana za pomocą wskaźnika zbudowanego $\mathrm{z}$ odpowiedzi na pytania zawarte w ramce 2 .

Ramka 2.

\begin{tabular}{|c|l|}
\hline s34 & $\begin{array}{l}\text { Osoba A potrafi rozkręcić zabawę na przyjęciu. Osoba B często milczy w towarzystwie } \\
\text { innych ludzi. }\end{array}$ \\
\hline s35 & $\begin{array}{l}\text { Na spotkaniach, Osoba A czuje się nieswojo będąc w centrum zainteresowania. } \\
\text { Osoba B jest często duszą towarzystwa. }\end{array}$ \\
\hline s37 & $\begin{array}{l}\text { Osoba A zazwyczaj kieruje przebiegiem rozmowy z innymi. Osoba B często milczy } \\
\text { w towarzystwie innych ludzi. }\end{array}$ \\
\hline s38 & $\begin{array}{l}\text { Osoba A najlepiej się czuje w towarzystwie osób dobrze sobie znanych. Osoba B równie } \\
\text { dobrze czuje się w towarzystwie nowych osób. }\end{array}$ \\
\hline
\end{tabular}

Czym różni się niska reaktywność od ekstrawersji? Współczynniki korelacji między kwestionariuszowymi wskaźnikami obu zmiennych są bardzo wysokie, ponieważ na poziomie układu nerwowego obie te cechy mają „identyczną" charakterystykę relacji procesów pobudzenia do procesów hamowania korowego. Zarówno WR, jak i introwertycy mają chronicznie podwyższony poziom aktywacji, zaś NR i ekstrawertycy obniżony, więc potrzebują więcej stymulacji. U ekstrawertyków obserwuje się dominację szlaku nerwowego związanego z dopaminą. Przykładem wyższej reaktywności introwertyków jest fakt, że po wyciśnięciu kropli cytryny na język wydzielają więcej śliny niż ekstrawertycy, co jest wyjaśniane wyższą aktywnością tworu siatkowatego.

Dla naszego toku wywodu można założyć, że zarówno NR, jak i ekstrawertycy 
mają „filtr" redukujący stymulację, więc mają na nią większe zapotrzebowanie. Ekstrawertywny pracownik będzie zaspokajał swoje duże zapotrzebowanie na stymulację w relacjach społecznych. NR pracownik może być samotnikiem i zaspokajać swoje zapotrzebowanie na stymulację, podejmując bardzo ryzykowne wyzwania intelektualne. Wysoka korelacja między NR i ekstrawersją wynika $z$ faktu, że to inni ludzie są najsilniejszym źródłem stymulacji.

Konstrukt teoretyczny „POSZUKIWANIE DOZNAN" operacjonalizowany skalą Zuckermana nie jest cechą jednorodną. Kwestionariusz składa z się 4 skal:

1) Poszukiwanie Grozy i Przygód (Thrill and Adventure Seeking),

2) Poszukiwanie Przeżyć (Experience Seeking),

3) Rozhamowanie (Disinhibition),

4) Wrażliwość na Nudę (Boredom Susceptibility).

Skala Zuckermana nie bierze pod uwagę różnych typów stymulacji, które mogą zaspokajać potrzebę doznań (o czym piszemy więcej w punkcie 4$)$. $Z$ tych względów w badaniach prowadzonych w Katedrze Psychologii i Socjologii Zarządzania koncentrujemy się na diagnozie reaktywności wynikającej z tonicznego PAO jako najmniej obciążonej wyborem typu stymulacji mającej dostarczyć pobudzenia.

Rysunek 2. Schematyczny wykres zależności między PAO a poziomem wykonania zadań dla osób wysoko i niskoreaktywnych

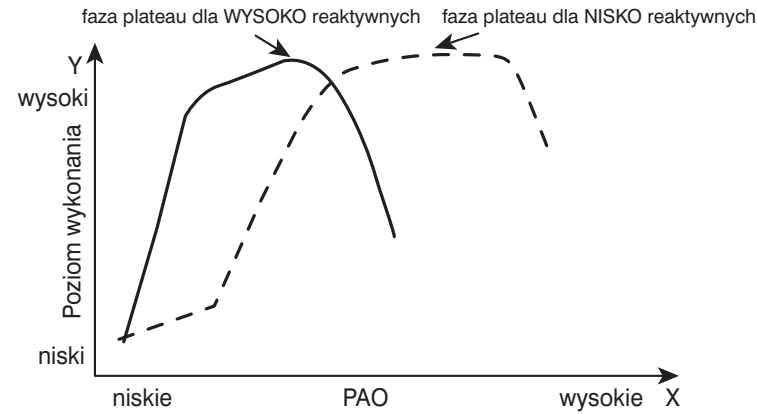

Źródło: opracowanie własne na podstawie literatury.

Krzywe opisane przez prawa YD maja inny kształt dla NR i WR (zob. rysunek 2). NR pracownicy o silnej potrzebie stymulacji w przypadku zbyt małej liczby bodźców (np. nudne wielogodzinne zebranie) odczuwają dyskomfort, czasem w postaci niezrozumiałego niepokoju. Brak stymula- cji zewnętrznej mogą kompensować sobie, poszukując wewnętrznych źródeł aktywacji, takich jak fantazje, intensywne wyobrażenia, plastyczne marzenia na jawie lub podejmując aktywność (zadając pytania, zgłaszając wnioski formalne, pisząc liściki z komentarzami do sąsiada).

Choć w podręcznikach optymalny poziom pobudzenia jest obrazowany jako punkt, sensowniej jest mówić o przedziale optymalnego pobudzenia. W analizie zależności poziomu pobudzenia do poziomu wykonania zadania (efektywność) widoczne jest to, że u osób wysoko reaktywnych poziom efektywności wzrasta wraz z poziomem pobudzenia, osiaggając ,plateau”, po czym zaczyna szybko spadać. U osób nisko reaktywnych poziom efektywności natomiast również wzrasta wraz z pobudzeniem, ale potrzebują one więcej czasu na wdrożenie się.

Druga istotną kwestią jest to, że osoby nisko reaktywne po osiagnięciu „plateau” utrzymuja ten stan jeszcze przez jakiś czas, czyli spadek pobudzenia nie jest tutaj tak szybki jak w przypadku osób wysoko reaktywnych. Nisko reaktywni mają szersze „plateau”, moga się zatem łatwiej dopasować do warunków pracy. Ma to również wpływ na to, jak oba typy ludzi działają pod wpływem presji czasowej. To co powoduje uczucie "rozpadu pod wpływem presji” u jednych (wysoko reaktywnych), wywołuje efekt „uskrzydlenia” u drugich (nisko reaktywnych). Czują się oni pełni energii i ze zwiększoną energią przystępują do wykonania zadania. Działają lepiej pod wpływem presji czasowej. Wysoko reaktywni będą czuć się bezpieczniej w sytuacjach bardziej przewidywalnych, na przykład wtedy, gdy wszystko jest $z$ góry ustalone: terminy, zasady działania i współpracy.

Oznacza to, że nie można wyznaczyć tego samego poziomu optymalnego obciążenia dla wszystkich, ale dla każdej osoby można wyznaczyć jej indywidualny poziom optymalnego obciążenia poznawczego, na które składa się wiele czynników choćby na przykład wpływ stresu, jego poziom czy też chęć, aby dobrze wypaść przed swoim szefem.

Dla lepszej efektywności pracy ważne jest, aby wiedzieć, w którym miejscu tego wykresu znajdujemy się my sami, a w którym na przykład nasi współpracownicy. Należy przy tym pamiętać, że poziom reaktywności pracownika może być modyfiko- 
wany przez chorobę, wieloletnie stresujące wydarzenia

\section{Pobudzenie fazowe pracownika jest moderowane przez automatycznie działajace filtry percepcyjne, schematy poznawacze, ale także celową aktywność poznawczą przypisującą znaczenie bodźcom}

W pracy, zwłaszcza gdy pracujemy w open space, oddziałuje na nas wiele bodźców - dzwoni telefon, uwiera nas krzesło, na którym siedzimy, zaczynamy się czuć zmęczeni, głodni, w głowie mamy ostatnią kłótnię z szefem, poranne spięcia rodzinne czy myśli o zbliżającym się weekendzie. Wszystkie te bodźce można podzielić na te, które są związane z wykonywaną pracą i te, które nas od niej odciagają - czyli dystraktory.

W tekście używamy zamiennie pojęć: „bodziec”, „sygnał”, „informacja”, ponieważ potoczne rozumienie pojęcia ,informacja” je utożsamia. Dla potrzeb opisywanego modelu nie musimy różnicować tych pojęć, choć trzeba pamiętać, że jest to duże uproszczenie.

Poziom pobudzenia organizmu, określany inaczej poziomem ogólnej aktywacji, jest efektem oddziaływania wszystkich rejestrowanych przez nasz organizm (świadomie lub nie) bodźców (zewnętrznych i wewnętrznych) określanych ogólnie jako stymulacja. Możemy więc powiedzieć, że im więcej stymulacji, tym wyższy poziom pobudzenia/poziom aktywacji. Oddziałujące na pracownika bodźce (zewnętrzne i wewnętrzne) można uporządkować na wymiarze kontrolowalności. Muzykę możemy wyłączyć, krzesło zmienić, głód usunąć posiłkiem, ale już pozbycie się zmęczenia lub przykrych myśli może być o wiele trudniejsze.

Mamy więc do czynienia z ciągłym dopływem stymulacji, która pełni funkcję sygnałową (dzięki interpretacji znaczenia) i ogólnie pobudzającą (np. głośność dźwięku).

Funkcja pobudzająca zależy nie tylko od obiektywnych cech bodźca, ale także od jego interpretacji, co wymaga paru zdań komentarza odnośnie do selekcji i interpretowania napływających bodźców. Wiele bodźców nie dociera do naszej świadomości
- np. nie czujemy, jak uciskaja nas okulary, ponieważ nasz naturalny filtr blokuje tego typu sygnały. Możemy jednak świadomie skierować naszą uwagę na odczucia w danym rejonie ciała i wtedy ten sygnał przez chwilę nie będzie odfiltrowywany.

Najważniejszy podział wszystkich rejestrowanych przez nasz organizm sygnałów dotyczy poziomu ich uświadomienia. Większość $\mathrm{z}$ nich nigdy nie znajdzie się w polu świadomości, choć moga one wzbudzać nieświadome reakcje emocjonalne i przez to wpływać na poziom pobudzenia organizmu pracownika.

Analiza każdej docierającej do nas informacji wymaga umiejętności skupienia uwagi umożliwiającej selekcję bodźców (zewnętrznych i wewnętrznych), pominięcie lub przynajmniej zablokowanie tych, które mają mniejsze znaczenie. Wszelkie szczegóły zatrzymuje się w pamięci tak długo, jak jest to konieczne do wykonania danej czynności. Następnie niepotrzebne wiadomości całkowicie z niej ulatują, aby przetrwać dłużej, muszą przykuć naszą uwagę (np. być nowe, głośne, cudowne, przerażające).

Selekcja sygnałów odbywa się na poziomie bardziej pierwotnym niż pole świadomości. Badania wykorzystujące neuroobrazowanie mózgu pokazały, że mózg reaguje tylko na reklamy telewizyjne związane z wyświetlanym filmem. W przypadku reklam niepowiązanych nie zanotowano reakcji wskazujących na „ożywienie” mózgu. „Wchodzą” jedynie sygnały, w jakiś sposób powiązane z tym, czym aktualnie zajmuje się umysł (Wieczorkowska, 2011).

Warto pamiętać o 3 typach automatycznych filtrów:

1) Filtry biologiczne /neurologiczne (tylko niewielka część rzeczywistości jest przez nas odbierana - większość bodźców jest zbyt słaba, aby zapoczątkować reakcję pobudzenia aksonu, z olbrzymiej liczby bitów docierających do zmysłów w ciągu każdej sekundy możemy uświadomić sobie jedynie bardzo niewielką część szacowaną na 0,0000001$)$.

2) Filtry kulturowe (nabywane w trakcie warunkowania i nauki języka, np. spostrzegamy to, co potrafimy nazwać - padający śnieg wymaga większej aktywności poznawczej Eskimosa - rozróżnianie 22 typów - niż Europejczyka). Ewolucyjnie wykształcone reakcje powodują, że pewne bodźce, np. zagniewane 
twarze, węże i pająki, zauważamy szybciej (uwaga mimowolna) niż obiekty obojętne. Pojawia się też wzrost PAO (emocjonalna reakcja alarmowa). Naukowcy zajmujący się zawodowo wężami też zauważają je szybciej niż żaby, ale nie wiąże się to ze wzrostem PAO, ponieważ nastąpiła u nich habituacja. $\mathrm{Na}$ emocjonalne sterowanie uwagą jesteśmy najbardziej podatni w sytuacjach natłoku informacji. Porwanie uwagi przez emocje skutkujące wzrostem PAO opisane jest przez Golemana (2014) następująco:

„Kiedy doznajemy emocjonalnego porwania, neurony $\mathrm{w}$ ciele migdałowatym "porywają" prawą stronę mózgu i przejmują nad nią kontrolę. Jednak lewa strona może przesyłać w dół sygnały, które uspokajają ciało migdałowate i wyprowadzają nas $\mathrm{z}$ sytuacji emocjonalnego porwania. Odporność emocjonalna sprowadza się do tego, jak szybko potrafimy się otrząsnąć, kiedy coś nas zdenerwuje. U osób o wysokiej odporności emocjonalnej - takich, które umieją się otrząsnąć natychmiast aktywność neuronalna w lewym obszarze kory przedczołowej bywa do trzydziestu razy silniejsza niż u osób bardziej podatnych na emocje".

3) Filtry indywidualne (pewne kategorie informacji odbieramy intensywniej niz inne, np. podczas gdy koncert Bacha dla jednych może być bodźcem w pełni analizowalnym - pobudzającym do analizy gry poszczególnych instrumentów czy refleksji nad aranżacją, dla innych jest bodźcem unitarnym - nie stymuluje mózgu do analizy, a jedynie stanowi mniej lub bardziej przyjemne tło).

Nie uświadamiamy sobie działania filtrów, ponieważ są one aktywizowane automatycznie. Nawet jeśli bodziec jest odbierany przez naszą świadomość, to siła pobudzenia zależy od interpretacji tego bodźca. Rozważmy zależność między siłą sygnału a siłą reakcji organizmu wpływającą na POA organizmu pracownika na paru przykładach. Pracujący młot pneumatyczny za ścianą daje silny sygnał dźwiękowy i trudno będzie przy nim zasnać, ale równie silny efekt może wywołać słaby bodziec - myśl o dziwnym dzisiejszym zachowaniu szefa, które może sugerować zagrożenie dla dalszego zatrudnienia. Wiadomość, że szykują się zwolnienia z pracy lub wyznanie miłosne w sposób magiczny usuwa senność, z którą zmagaliśmy się po nieprzespanej nocy, pod warunkiem, że jest to dla nas niespodziewana informacja. Obiektywnie nasz organizm potrzebuje snu, ale subiektywnie po otrzymaniu takich wiadomości trudno byłoby nam zasnąć.

\section{Pracownik zazwyczaj aktywnie wpływa na PAO, podejmując działania o określonej wartości stymulacyjnej. Widoczne są duże różnice $w$ preferencjach co do typu stymulacji (intelektualna, fizyczna, społeczna)}

Pracownicy różnią się zapotrzebowaniem na stymulację - jedni potrzebują jej więcej, aby osiagnąć optymalny poziom stymulacji, inni mniej. Dodatkowa aktywność pracowników przejawiająca się w ilości i zakresie podejmowanych działań o określonej wartości stymulacyjnej, odgrywa istotną rolę $\mathrm{w}$ regulacji poziomu aktywacji. Pracownicy starają się przeciwdziałać nadmiernym odchyleniom swojego pobudzenia od optimum, czyli odpowiednio sterować różnymi wewnętrznymi i zewnętrznymi źródłami, w tym także własnych zachowaniem. Piją kawę (gdy chcą się pobudzić) lub melisę, gdy chcą się uspokoić. Biegają lub medytują....

Badacze wydają się nie brać pod uwagę, że konstrukt teoretyczny pasma optymalnej aktywacji nie różnicuje jej źródeł (Wieczorkowska, 2011a). O ile można pokusić się o porównywanie wartości stymulacyjnej 30-minutowego spaceru i 10-minutowego biegu, o tyle takie samo porównanie sprintu z aktywacją spowodowaną przyjemną bądź nieprzyjemną rozmową z szefem jest bardziej skomplikowane. Im częstsza aktywność danego typu, tym mniejsza jej wartość stymulacyjna. Im częściej ćwiczymy, tym bardziej rozwinięte są nasze mięśnie i tym bardziej intensywnych bodźców potrzebujemy dla uzyskania tego samego poziomu pobudzenia.

Możemy być przemęczeni/przestymulowani intelektualnie, ale $\mathrm{z}$ chęcią będziemy poszukiwać stymulacji motorycznej, idąc na basen. Po dniu spędzonym w zgiełku, gdy czujemy się bardzo przeciążeni stymulacją społeczną, możemy z przyjemnością szukać stymulacji intelektualnej. Badania pokazujace negatywne skutki deprywacji sensorycznej są powszechnie znane. Nie znalazłyśmy jednak badań dotyczących 
skutków deprywacji poszczególnych typów stymulacji

Pytana przez nas w pytaniu otwartym grupa ponad 130 uczestników zajęć nie miała wątpliwości: brak jakiego typu stymulacji (społecznej, motorycznej czy intelektualnej) jest dla nich najtrudniejszy do zniesienia. Parę wypowiedzi w ramce poniżej:

@Lubię ludzi wokól siebie - dla towarzystwa dałbym się pokroić - ludzie są też dla mnie doskonałą mobilizacją intelektualną. Interwałowe pływanie jest doskonałym odreagowaniem stresu. Na zbyt dużą ilość bodźców mój organizm reaguje automatycznie - zasypiam, gdziekolwiek poczuję się w miarę komfortowo.

@@Preferuję samotność. Informacje o innych i otaczającym świecie wolę zdobywać poprzez obserwację, niż poprzez wchodzenie w interakcję z innymi ludźmi. Stymulacja fizyczna - to jest to, co lubię najbardziej. Staram się codziennie przepłynąc kilometr. W samotności. Stymulacja intelektualna - wolę konkretne działanie niż myślenie o „niebieskich migdałach”.

@@@estem raczej typem samotnika, chociaż są osoby, z którymi mogłabym rozmawiać godzinami i sprawia mi to dużą przyjemność. Sama ze sobą się nie nudzę. Uwielbiam jazdę na rowerze, pływanie, taniec. Czasami, gdy mam jakiś problem, wybieram jakąś dynamiczną muzykę i biegam. Potrzeba stymulacji intelektualnej jest chyba u mnie najsilniejsza. Gdybym mogła, myślałabym godzinami.

@@@@ trudem nawiązuję nowe kontakty i sporo czasu musi minąć, nim kogoś zaakceptuję jako bliską osobę. Wolę spokojne wspólne spędzanie czasu niż szaleństwo całonocnej zabawy. Z aktywności fizycznych najbardziej lubię wędrówki, piesze lub rowerowe. Gdy zostaję sama, nigdy się nie nudzę - mogę siedzieć w fotelu, rozmyślać, słuchać śpiewu ptaków albo dyskusji w radio.

W badaniach Wieczorkowskiej (2011) za pomocą analizy skupień metodą k-średnich podzielono 570 respondentów z wyższym wykształceniem pod względem deklarowanego poziomu 3 typów aktywności: fizycznej, intelektualnej i społecznej na 5 kategorii:

- hipoaktywnych (niski poziom wszystkich 3 typów),

- hiperaktywnych (wysoki poziom wszystkich 3 typów),
- aspołecznych (o najniższym poziomie aktywności społecznej),

- afizycznych (o najniższym poziomie aktywności fizycznej),

- aintelektualnych (o najniższym poziomie aktywności intelektualnej).

Następnie porównano te pięć grup pod względem możliwości energetycznych, które były operacjonalizowane przez wskaźnik zbudowany z odpowiedzi na 4 pytania $(\alpha$ Cronbacha $=0,72)$ zawarte $\mathrm{w}$ ramce poniżej.

1. Osoba A jest w stanie kontynuować pracę, pomimo zmęczenia. Osoba B musi robić kilka przerw na odpoczynek.

2. Osoba A, gdy śpi mniej niż normalnie, czuje się rozbita i zmęczona. Osoba B potrafi intensywnie pracować po nieprzespanej nocy.

3. Osoba A jest bardzo zmęczona, jeśli przez kilka godzin wykonywała coś w skupieniu. Osoba B dobrze znosi pracę bez przerwy.

4. Osoba A zachowuje świeżość i siły, nawet po długiej podróży. Osoba B musi najpierw porządnie odpocząć.

Grupa hiperaktywnych (wysokie wyniki na wszystkich 3 wymiarach) charakteryzowała się istotnie wyższą wytrzymałością od grupy aspołecznych (najniższa aktywność społeczna) i grupy hipoaktywnych (niskie wyniki na wszystkich 3 wymiarach). Róż- 
nice poza pozostałymi grupami były nieistotne statystycznie. Oznacza to, że przy tym samym poziomie możliwości energetycznych można preferować różne konfiguracje typów stymulacji.

Warto jednak zwrócić uwagę, że deklarowany poziom aktywności społecznej jest najlepszym predyktorem wytrzymałości. To wyjaśnia tak wysokie korelacje między reaktywnością a ekstrawersją. Poziom aktywności intelektualnej nie koreluje $\mathrm{z}$ temperamentem.

Trzeba oczywiście podkreślić, że wykorzystany podział na typy stymulacji nie jest ostry (np. aerobik jest klasycznym przykładem połączenia aktywności społecznej i motorycznej). Nie jest także wyczerpujący, ponieważ warto byłoby wyodrębnić też stymulację sensoryczną czy emocjonalną (np. angażowanie się w kłótnie jest zasobożerne).

Warto jednak podkreślić, że funkcją aktywności pracownika nie jest tylko pragnienie osiagnięcia optymalnego poziomu aktywacji, ale przede wszystkim realizacja zadań, które musi wykonać. Niektórzy pracownicy mogą marzyć o stanowiskach dyrektorskich, mimo że ich możliwości energetyczne wyznaczone przez temperament sa bardzo ograniczone. W czasie socjalizacji mogli się oni zidentyfikować ze stylem życia osób o różnych od nich ograniczeniach energetycznych. Nagrodą za podejmowanie aktywności zgodnej $\mathrm{z}$ naszym temperamentem jest dobre samopoczucie, ale równie konkurencyjnie nagradzające może być podejmowanie aktywności niedopasowanej do temperamentu, jeśli jest ona zgodna z naszymi marzeniami czy oczekiwaniami. Nasza aktywność (jej poziom wymuszany lub nie przez wymagania pracy, styl działania) może być więc spójna lub niespójna z wyznaczonymi przez temperament potrzebami i możliwościami przetwarzania stymulacji (Eliasz i Klonowicz, 2003).

Pracownicy wysoko reaktywni mogą zupełnie świadomie wybierać zawody prowadzące ich do przeciążenia, które może zakończyć się wypaleniem zawodowym (burn-out). Na drugim końcu wymiaru mogą znajdować się niewykorzystywani dostatecznie silnie pracownicy o dużych zasobach poznawczych, którzy znajduja się w sytuacji chronicznego niedociążenia, które może zakończyć się „alienacją” zawodową (bore-out).
Przykładem niedociążenia są osoby nisko reaktywne, nudzące się w rutynowej pracy. Nie stanowi to jednak problemu, ponieważ wolne zasoby poznawcze moga być wykorzystane do innych aktywności (np. rodzina, hobby, praca społeczna). Niespójności polegające na przeciążaniu organizmu są natomiast bardzo niebezpieczne. W badaniach (Eliasz, 1995) pokazano, że osoby wysoko reaktywne, przejawiające $\mathrm{w}$ pracy kierowniczej wzór zachowania A (charakteryzujący się wysoką potrzebą osiągnięć, tendencją do dominacji, agresywnością, wysoka dynamiką zachowań, chronicznym brakiem czasu, niecierpliwością i pośpiechem połączonym $\mathrm{z}$ wrogością wobec tych, którzy stoją na przeszkodzie), nie potrafią różnicować sytuacji pracy i wypoczynku. Osoby nisko reaktywne zachowują się zgodnie ze stylem A tylko w pracy, w domu „odpuszczają", co pozytywnie wpływa na ich zdrowie.

W badaniach (Wieczorkowska, 2011a) pokazano również, że nadmiar aktywności w stosunku do możliwości organizmu (przeciążenie) przekłada się na lepsze samopoczucie niż jej niedostatek przy niskiej presji środowiskowej, zaś gorszy bilans emocjonalny przy dużej presji. Każdy z analizowanych typów aktywności ma więc pozytywny wpływ na nasze samopoczucie, jeśli nie przekracza naszych możliwości energetycznych w sytuacji silnej presji środowiskowej. Krótko mówiąc: konsekwencje braku spójności między temperamentem i poziomem aktywności zależą od wymagań środowiskowych.

\section{Zakończenie}

Nieoptymalne obciążenie poznawcze pracownika może prowadzić do wypalenia (burnout) lub alienacji (bore-out). Warto pamiętać, że przeciążenie poznawcze w pracy nie wynika tylko z ilości bodźców, wielozadaniowości (Król, 2017). Warunkiem koniecznym dla doświadczenia nadmiaru informacji jest motywacja, aby nadać tym informacjom znaczenie, jakoś je uporządkować. Pobyt w bibliotece naukowej czy muzeum jest przeciążający tylko dla kogoś, kto próbuje napływające informacje uporządkować, nadać im sens. Porządkowanie jest tym łatwiejsze, im bardziej oczywiste są porządkujące kryteria. Status oczywistości (Marody, 2015) mają kryteria podzielane przez grupę, której jesteśmy częścią. Nie 
dziwi więc fakt, że poczucie osamotnienia okazało się najlepszym predyktorem przeciążenia poznawczego (Wieczorkowska, 2017). Przeciążenie pracowników może wynikać z rozpowszechnionego indywidualizmu. Jesteśmy przekonane, że zespołowe rozliczanie pracowników z efektów pracy mogłoby temu przeciwdziałać, ale najpierw trzeba to sprawdzić w badaniach.

\section{Przypisy}

1 SSA - Sondaż Stylów Aktywności to narzędzie diagnostyczne używane do badań w KPISZ WZ UW oparte na Inwentarzu Stylów Aktywności (Wieczorkowska, 1998).

\section{Bibliografia}

*Pozycje zaznaczone gwiazdką są w tekście cytowane za pomocą pierwszego nazwiska.

Bodenhausen, G.V. (1990). Stereotypes as Judgmental Heuristics: Evidence of Circadian Variations in Discrimination. Psychological Science, 1(5), 319-322, https://doi.org/10.1111/j.1467-9280.1990. tb00226.x

Duch, W. (2018). Materiaty do wyktadów z neurokognitywistyki. Dostępne na stronie http://www.is.umk. pl/ duch/Wyklady/Kog1/01-wstep.htm

Eliasz, A. i Klonowicz, T. (2003). System regulacji stymulacji. Teoretyczne znaczenie pojęcia. W: M. Marszał-Wiśniewska, T. Klonowicz, M. Fajkowska-Stanik (red.), Psychologia różnic indywidualnych (s. 88-103). Gdańsk: Gdańskie Wydawnictwo Psychologiczne.

Goleman, D. (2014). Focus. Sztuka koncentracji jako ukryte dążenie do doskonatości. Poznań: Media Rodzina.

Król, G. (2017). Individual differences in dealing with overflow. European Management Jour- nal, 35(6), 794-802, https://doi.org/10.1016/j. emj.2017.07.003

Jarymowicz, M. i Imbir, K. (2010). Próba taksonomii ludzkich emocji. Przeglad Psychologiczny, 53(4), 439-461.

Marody, M. (2015). Jednostka po nowoczesności: perspektywa socjologiczna. Warszawa: Wydawnictwo Naukowe Scholar.

Strelau, J. (2006). Temperament jako regulator zachowania z perspektywy pótwiecza badań. Gdańsk: Gdańskie Wydawnictwo Psychologiczne.

Thayer, R.E. (1989). The biopsychology of mood and arousal. New York, US: Oxford University Press.

*Wieczorkowska-Nejtardt, G. (1998). Inteligencja motywacyjna: madre strategie wyboru. Warszawa: Wydawnictwa Instytutu Studiów Społecznych.

*Wieczorkowska-Wierzbińska, G. (2011). Psychologiczne ograniczenia. Warszawa: Wydawnictwo Naukowe Wydziału Zarządzania UW.

*Wieczorkowska-Wierzbińska, G. (2011a). System Regulacji Stymulacji: styl działania, poziom i typ aktywności oraz temperament. W: J. Strelau i M. Marszał-Wiśniewska (red.), Uwiktany temperament: osobowość, temperament, środowisko (s. 71-92). Warszawa: Wydawnictwo Naukowe Scholar.

*Wieczorkowska-Wierzbińska, G. (2017). Dealing with too much. European Management Journal, 35(6), 803-805, https://doi.org/10.1016/j. emj.2017.10.002

Yerkes, R.M. i Dodson, J.D. (1908). The relation of strength of stimulus to rapidity of habitformation. Journal of Comparative Neurology and Psychology, 18(5), 459-482, https://doi.org/10.1002/ cne.920180503

Ziomek, M. i Brola, W. (2006). Przemijająca niepamięć ogólna (tom 4). Kielce: Studia Medyczne Akademii Świętokrzyskiej. 